\title{
リハビリテーションのアウトカム評価と ベンチマーク分析（オーストラリアの場合）
}

\section{渡辺百合子 \\ Sacred Heart Rehabilitation Service, St Vincent's Hospital Sydney, Australia}

\section{はじめに}

オーストラリアでも医療費の高騰が問題となっ ている.リハビリテーションにおいても，いかに医 療の質を保ちつつコストを下げ運営効率を上げる かが課題となっている．簡単にいえば入院 1 週間 あたりの Functional Independence Measure (FIM) の上昇率を上げ (FIM efficiency)，そして (入院に比べると) 安価な外来 (あるいは自宅での) リハビリテーションプログラムに早めにつなげてい けるか，となる．

しかし，どうやって自分たちのリハビリテーショ ン診療のパフォーマンスを評価するのか．他の病 院と比較する際には, ケースミックスなど入院患者 の特性の違いを考慮する必要がある，疾病ごとの 比較が重要であり, ベンチマーク分析が大事であ る.

\section{Australasian Rehabilitation Outcomes Centre (AROC)}

$\mathrm{AROC}^{1)}$ はオーストラリアとニュージーランドの 全リハビリテーション施設のレジストリである. 2002 年に設立され, リハビリテーションのアウトカ ム向上に必要なベンチマークシステムを開発し, デー夕の収集・解析を行っている。 入院リハビリ テーションプログラムに関しては，現在すべてのリ ハビリテーション施設がデー夕を提出しており $(100 \%), 2016$ 年は 119,583 のエピソード（リハビ リテーション病棟入院から退院までを 1 エピソー
ドと計算) が報告されている22. AROC はリハビリ テーション医学の学術集会の本会議で毎年結果を 報告している.

\section{データセット}

現在は AROC Version 4 が利用されている3,4). 機能評価は FIM を使用．主なアウトカムは入院期 間 (length of stay), FIM の変化（退院時 FIM 入院時 FIM), FIM の上昇率 (FIM efficiency), 退院先である.FIM を正しく使用できるように AROCでは FIM 講習も行っている. Impairment （機能障害）分類も細かく分かれている. 同じ診断 名でもリハビリテーション入院時の機能, 年齢で機 能予後, 入院期間が異なることから, これらを変数 として統計的重みをつけている。 Version 4 からは 入院時の FIM motor の各項目も診断別に重みを つけて計算している $\left(\right.$ weighted FIM) ${ }^{5}$.

\section{ベンチマーク分析結果}

各リハビリテーション施設には AROC からその 施設の結果 (ベンチマークとの比較, 前年度との比 較など）が毎年送られてくる。全体の結果は AROCのホームページに公表されており，誰でも アクセスできる2,6) (表 1)。リハビリテーションの 入院期間は年々短縮されており，2016 年は全体で 17.5 日間であった。また，2016 年では約半数 (50.6\%) のケースで疾病（症状）発生から 1 週間 以内にリハビリテーション病棟に入院してきてお 
表 1 オーストラリア全体のリハビリテーションのベンチマークー部抜粋2, 6) (脳卒中, 2016 年)

\begin{tabular}{|c|c|c|c|c|c|c|c|}
\hline 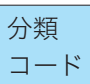 & 対象グループ & Age & $\begin{array}{l}\text { Admission } \\
\text { FIM }\end{array}$ & $\begin{array}{l}\text { Length of stay } \\
\text { (LOS) (day) }\end{array}$ & $\begin{array}{l}\text { FIM } \\
\text { change }\end{array}$ & $\begin{array}{l}\text { FIM } \\
\text { gain/week }\end{array}$ & $\begin{array}{l}\text { FIM efficiency（FIM } \\
\text { change/LOS） }\end{array}$ \\
\hline 4AA4 & $\begin{array}{l}\text { Weighted FIM motor } \\
36-50, \text { Age } \geq 68\end{array}$ & 81.2 & 78.3 & 27.9 & 27 & 6.8 & 1 \\
\hline 4AA6 & $\begin{array}{l}\text { Weighted FIM motor } \\
19-35, \text { Age } \geq 68\end{array}$ & 80.6 & 48.9 & 40.5 & 30 & 5.2 & 0.7 \\
\hline
\end{tabular}

り,この早期リハビリテーション入院の割合も年々 増加している.

これらのベンチマークをもとに, リハビリテー ション病棟に入院時の時点で退院日を仮設定する ことができ，患者のみならず家族も含め退院準備 を早めに開始することができる.

\section{注意する点}

リハビリテーションの現場でよく問題となる社会 心理的側面, つまり家屋状況, 患者本人や家族の 不安やストレスなどは，早期にリハビリテーション 介入を行っても FIMに反映されない.

\section{AROC の今後と研究との関連}

入院リハビリテーションプログラムに加え, 外来 リハビリテーションプログラム, また急性期病棟へ のリハビリテーション介入（通常の急性期病棟のリ ハビリテーションに加えてプラス $\alpha$ としてリハビリ テーションチームが介入する. In reach rehabilitation などと呼ばれる) などのデータを回収し始めて いる1). Impairmentによってどのリハビリテー ションプログラムが FIM の上昇率が高いかなど, 費用を意識した分析が期待できる．また，他の急 性期病態のレジストリ, 例えば脳卒中のレジストリ (Australian Stroke Clinical Registry) ${ }^{7,8)}$ や外傷レ ジストリ（NSW Trauma Registry） ${ }^{9}$ 10) とリンクさ せ (linkage study) 急性期から退院後まで大きな 1 つの流れとして分析し検討することが可能となり, 効率的な医療またはリハビリテーションの運営モ
デルやシステムの改善に役立つと思われる.

\section{文 献}

1) AROC : Australasian Rehabilitation Outcomes Centre. Available from URL : http://ahsri.uow.edu.au/ aroc/index.html（2017 年 7 月 29 日引用）

2) AROC : The AROC Annual Report: The state of rehabilitation in Australia (2016). Available from URL : http://ahsri.uow.edu.au/aroc/reports/index. $\mathrm{html}$ (2017 年 7 月 29 日引用)

3) AROC : AROC Inpatient Clinical Dataset. Available from URL : http://ahsri.uow.edu.au/aroc/inpatient dataset/index.html（2017 年 7 月 29 日引用）

4) AROC : Australia, Inpatient V4, Direct inpatient care, pathway 3 . Available from URL : https://apps. ahsri.uow.edu.au/confluence/display/AD/Data+Col lection+Forms（2017 年 7 月 29 日引用）

5) AROC : The Australian National Subacute and Nonacute patient (AN-SNAP) classification, Version 4 User Manual. Available from URL : http://ahsri.uo w.edu.au/aroc/an-snapv4/index.html（2017 年 7 月 29 日引用）

6) AROC : Calendar year benchmarks (2016) -Australia. Available from URL : http://ahsri.uow.edu.a

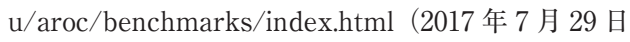
引用）

7) Australian Stroke Clinical Registry (AUSCR). Available from URL: http://www.auscr.com.au/ (2017 年 7 月 29 日引用)

8) Cadilhac DA, Lannin NA, Anderson CS, et al : On behalf of the AuSCR Consortium. The Australian Stroke Clinical Registry Annual Report 2015. The Florey Institute of Neuroscience and Mental Health ; December 2016, Report No 7, p 42

9) NSW Institute of Trauma and Injury Management: NSW Trauma Registry Annual Reports. Available from URL : https://www.aci.health.nsw.g ov.au/get-involved/institute-of-trauma-and-injury-m anagement/Data/trauma_data_reports/itim_annu al_trauma_registry_reports（2017 年 7 月 29 日引 用)

10) Wu J, Faux SG, Harris I, Poulos CJ : Integration of trauma and rehabilitation services is the answer to more cost-effective care. ANZ J Surg 2016;86 : 900-904 